\title{
Significance of Quantitative Interferon-gamma Levels in Non-small-cell Lung Cancer Patients' Response to Immune Checkpoint Inhibitors
}

\author{
TOMOHIRO KANAI ${ }^{1}$, HIDEKAZU SUZUKI ${ }^{1}$, HIROKO YOSHIDA ${ }^{2}$, AKANE MATSUSHITA ${ }^{2}$, \\ HIROMI KAWASUMI ${ }^{2}$, YUMIKO SAMEJIMA ${ }^{1}$, YOSHIMI NODA ${ }^{1}$, SHINGO NASU ${ }^{1}$, AYAKO TANAKA ${ }^{1}$, \\ NAOKO MORISHITA $^{1}$, SHOJI HASHIMOTO ${ }^{3}$, KUNIMITSU KAWAHARA ${ }^{4}$, YOSHITAKA TAMURA ${ }^{2}$, \\ NORIO OKAMOTO ${ }^{1}$, TOSHIO TANAKA ${ }^{3}$ and TOMONORI HIRASHIMA ${ }^{1}$ \\ ${ }^{I}$ Department of Thoracic Oncology, Osaka Habikino Medical Center, Osaka, Japan; \\ ${ }^{2}$ Department of Clinical Laboratory, Osaka Habikino Medical Center, Osaka, Japan; \\ ${ }^{3}$ Department of Allergy, Osaka Habikino Medical Center, Osaka, Japan; \\ ${ }^{4}$ Department of Clinical Pathology, Osaka Habikino Medical Center, Osaka, Japan
}

\begin{abstract}
Background/Aim: We aimed to study the association between the quantitative interferon-gamma (IFN$\gamma)$ levels and clinical outcomes in non-small-cell lung cancer (NSCLC) patients receiving immune checkpoint inhibitors (ICIs). Patients and Methods: Sample collection for IFN- $\gamma$ release assay (IGRA) was performed within 14 days before treatment (T1), on day $22 \pm 7$ (T3), and on day $43 \pm 7$ (T4). The stored specimens over $10 \mathrm{IU} / \mathrm{ml}$ in IGRA were re-examined using the dilution method (with saline as the dilution medium). The patients were classified into Lower and Higher groups by $7.06 \mathrm{IU} / \mathrm{ml}$ as a cut-off of IFN- $\gamma$ levels at T1. Results: Median progression-free survival in the Higher group was significantly longer than that in the Lower group. IFN- $\gamma$ levels in the nonprogression disease group were significantly higher than those in the progression disease group. IFN- $\gamma$ levels at $T 1$ in patients with immune-related adverse events were significantly lower compared to those at T3. Conclusion: IFN- $\gamma$ could be a biomarker for NSCLC patients receiving ICIs.
\end{abstract}

Immune checkpoint Inhibitors (ICIs) are widely used as immunotherapy for a number of cancers. Cytotoxic Tlymphocyte-associated antigen 4 antibodies for melanoma

This article is freely accessible online.

Correspondence to: Dr. Tomohiro Kanai, MD, Department of Thoracic Oncology, Osaka Habikino Medical Center, 3-7-1, Habikino, Habikino city, Osaka, 583-8588, Japan. Tel: +81 729572121, Fax: +81 729578002, e-mail t.kanai777@gmail.com

Key Words: Interferon-gamma, immune checkpoint inhibitor, nonsmall-cell lung cancer, immune-related adverse event. were the first ICIs used in a clinical situation (1). After the programmed cell death-1 (PD-1) gene was cloned (2), an anti-PD-1 antibody (3) was also rapidly developed as one of the ICIs. Apart from treating melanomas, ICIs are being approved for different types of cancers, such as lymphomas (4) and gastric cancers (5).

Non-small cell lung cancer (NSCLC) is one of the cancers usually treated with ICIs $(6,7)$. Programmed death-ligand 1 (PD-L1) is highly expressed in NSCLC and is the only biomarker that is used in the clinical practice to predict response to ICIs (8). However, this biomarker is not ideal because in some patients ICIs were less effective, even when PD-L1 expression level was high. In previous studies, many factors have been reported as biomarkers for ICIs response (9). However, none of the biomarkers were more effective than PDL1. In our recent study (10), we examined the association between clinical outcomes of ICIs and levels of interferongamma (IFN- $\gamma$ ) release. We concluded that changes in the PD1/PD-L1 axis by ICI treatment affected IFN- $\gamma$ release by T lymphocytes, and IFN- $\gamma$ levels could be a biomarker for the early detection of severe immune-related adverse events (irAEs), such as ICI-induced interstitial pneumonitis (ICI-IP), and for patient selection for ICI treatment. However, in our previous study (10) IFN- $\gamma$ was examined qualitatively with an upper cut-off level of $10 \mathrm{IU} / \mathrm{ml}$, while quantitative levels of IFN- $\gamma$ in response to ICI are still unknown. As a result, the patients enrolled in our previous study were classified into three groups according to the IFN- $\gamma$ levels at pre-treatment and on treatment, because the cut-off level of interferon-gamma release assay (IGRA) was $10 \mathrm{IU} / \mathrm{ml}$. Because of this limitation in our previous study, we herein quantitatively re-examined the levels of IFN- $\gamma>10 \mathrm{IU} / \mathrm{ml}$ using the dilution method (with saline as the dilution medium). 
Table I. Baseline patient demographics and laboratory data according to the level of positive control of interferon-gamma release assay before immune checkpoint inhibitor treatment.

\begin{tabular}{|c|c|c|c|c|}
\hline \multirow[t]{2}{*}{ Variables } & \multirow[t]{2}{*}{ Overall } & \multicolumn{2}{|c|}{ IFN- $\gamma(\mathrm{IU} / \mathrm{ml})$ level } & \multirow[t]{2}{*}{$p$-Value } \\
\hline & & $\leq 7.06(\mathrm{n}=5)$ & $>7.06(n=24)$ & \\
\hline \multicolumn{5}{|l|}{ Gender } \\
\hline Male & 24 & 5 & 19 & 0.55 \\
\hline Female & 5 & 0 & 5 & \\
\hline \multicolumn{5}{|l|}{ Age } \\
\hline Median (range) & & $67(55-75)$ & $74(44-84)$ & 0.25 \\
\hline \multicolumn{5}{|l|}{ Performance status } \\
\hline 0 & 2 & 0 & 2 & 0.54 \\
\hline 1 & 17 & 2 & 15 & \\
\hline 2 & 10 & 3 & 7 & \\
\hline \multicolumn{5}{|l|}{ Histology } \\
\hline Adenocarcinoma & 24 & 4 & 20 & 0.64 \\
\hline Squamous cell carcinoma & 3 & 1 & 2 & \\
\hline Others & 2 & 0 & 2 & \\
\hline \multicolumn{5}{|l|}{ Stage } \\
\hline IIIB-C & 3 & 1 & 2 & 0.6 \\
\hline IV & 18 & 3 & 15 & \\
\hline Recurrence & 8 & 1 & 7 & \\
\hline \multicolumn{5}{|l|}{ PD-L1 staining } \\
\hline$<1 \%$ & 6 & 2 & 4 & 0.5 \\
\hline$>1 \%,<50 \%$ & 6 & 0 & 6 & \\
\hline$>50 \%$ & 15 & 3 & 12 & \\
\hline Unknown & 2 & 0 & 2 & \\
\hline \multicolumn{5}{|l|}{ Driver mutation } \\
\hline Yes & 1 & 1 & 0 & 0.17 \\
\hline No & 28 & 4 & 24 & \\
\hline \multicolumn{5}{|l|}{ Treatment line } \\
\hline First & 13 & 2 & 11 & 0.04 \\
\hline Second & 10 & 0 & 10 & \\
\hline Third or more & 6 & 3 & 3 & \\
\hline \multicolumn{5}{|l|}{ Immune checkpoint inhibitor } \\
\hline Pembrolizumab & 17 & 2 & 15 & 0.31 \\
\hline Atezolizumab & 7 & 1 & 6 & \\
\hline Nivolumab & 5 & 2 & 3 & \\
\hline \multicolumn{5}{|l|}{ Body mass index $\left(\mathrm{kg} / \mathrm{m}^{2}\right)$} \\
\hline Mean \pm S/D & & $20.76 \pm 2.47$ & $23.06 \pm 4.15$ & 0.26 \\
\hline \multicolumn{5}{|l|}{ Laboratory data $($ Mean \pm S/D) } \\
\hline Neutrophi-lymphocyte ratio & & $5.8 \pm 2.0$ & $4.72 \pm 3.48$ & 0.07 \\
\hline Lymohocyte $(/ \mu \mathrm{l})$ & & $1119 \pm 452$ & $1241 \pm 462$ & 0.5 \\
\hline C-reactive protein $(\mathrm{mg} / \mathrm{dl})$ & & $5.72 \pm 5.79$ & $1.99 \pm 2.80$ & 0.078 \\
\hline Serum albumin $(\mathrm{g} / \mathrm{dl})$ & & $3.3 \pm 0.55$ & $4 \pm 0.55$ & 0.04 \\
\hline \multicolumn{5}{|l|}{ Best response (n) } \\
\hline Partial response & 4 & 0 & 4 & \\
\hline Stable disease & 9 & 0 & 9 & \\
\hline Progressive disease & 15 & 5 & 10 & \\
\hline Not evaluable & 1 & 0 & 1 & \\
\hline Disease control rate $(\%)$ & & 0 & 54.2 & 0.04 \\
\hline
\end{tabular}

ICI: Immune checkpoint inhibitor; IFN- $\gamma$ : interferon-gamma; S/D: standard deviation. Lower group: patients with $7.06 \mathrm{IU} / \mathrm{ml}$ or more in positive control before ICI treatment. Higher group: patients with more than $7.06 \mathrm{IU} / \mathrm{ml}$ in positive control before ICI treatment.

To that end, we evaluated the detailed change of IFN- $\gamma$ over $10 \mathrm{IU} / \mathrm{ml}$ and re-analysed the correlation between quantitative levels of IFN- $\gamma$ and clinical features or outcomes in NSCLC patients who received ICIs.

\section{Patients and Methods}

The included patients and methods are almost identical as in our previous report (10). 
Ethics statement. This study was approved by our Institutional Review Board (approval no.: 884) of our Institutions. All patients who participated in this study were enrolled after providing their written informed consent. Furthermore, this study was registered in the University Hospital Medical Information Network Clinical Trials Registry (UMIN000031881).

Patients. Inclusion and exclusion criteria were the same as described in our previous study (10). Pathologically diagnosed NSCLC patients at the Osaka Habikino Medical Center between July 17, 2018, and February 25, 2019, were enrolled in this study. The inclusion criteria were as follows: (i) a diagnosis of recurrent, unresectable stage III or IV NSCLC with measurable lesions, (ii) therapy with ICIs, such as nivolumab, pembrolizumab, and atezolizumab, (iii) consent to participate in the study, (iv) age 20 years or older, and (v) an Eastern Cooperative Oncology Group (ECOG) performance status of $\leq 2$. In contrast, patients who (i) had synchronous double tumors, (ii) had an active infectious or hepatic disease, (iii) intended to become pregnant, or (iv) were deemed by a physician to be ineligible for this study, were excluded.

Interferon-gamma release assay (IGRA) and sample collection. IGRA was performed with QuantiFERON ${ }^{\circledR}$-TB Gold Plus (QFTPlus; Qiagen, Germany) assay. Sample collection for IGRA was performed as described in our previous study (10) within 14 days before treatment (T1: day -14 to 1 ), on day $8 \pm 3$ (T2: day 5 to 11 ), on day $22 \pm 7$ (T3: day 15 to 29 ), and on day $43 \pm 7$ (T4: day 36 to 50). In this study, we examined samples at $\mathrm{T} 1, \mathrm{~T} 3$, and $\mathrm{T} 4$ except for samples at T2. QFT-puls included four blood collection tubes, (i) a nil control tube (negative control), (ii) tuberculosis 1 antigen tube, (iii) tuberculosis 2 antigen tube, and (iv) mitogen tube (positive control). We observed IFN- $\gamma$ changes in the positive control tube.

Examination and quantitative evaluation of interferon-gamma levels. All specimens were stored at $-80^{\circ} \mathrm{C}$. The specimen over 10 $\mathrm{IU} / \mathrm{ml}$ that served as the upper-limit in IGRA were first diluted 20 fold with physiological saline, and then diluted 2-fold until they become measurable by enzyme-linked immunosorbent assay (ELISA).

Cut-off levels of interferon-gamma in the positive control tube. Huang $\mathrm{HC}$ et al. reported that low levels of IFN- $\gamma$ were associated with low response to chemotherapy (11). They examined the positive control of IGRA and classified patients into two groups by $7.06 \mathrm{IU} / \mathrm{ml}$ as cut-off level of IFN- $\gamma$. Based on their cut-off levels, we re-analysed clinical outcomes in NSCLC patients who were treated with ICIs.

Progression-free survival. The progression-free survival (PFS) was compared between two groups, as categorized by the $7.06 \mathrm{IU} / \mathrm{ml}$ cut-off level of IFN- $\gamma$. PFS was defined from the time of administration of ICIs to the time of disease progression or death. The disease progression was determined by a computed tomography (CT) according to the Response Evaluation Criteria in Solid Tumors (RECIST) guideline version 1.1. The time of disease progression was defined as the date on which CT was conducted.

Statistical analyses. All analyses were conducted using the statistical software package R (12). PFS were compared using the

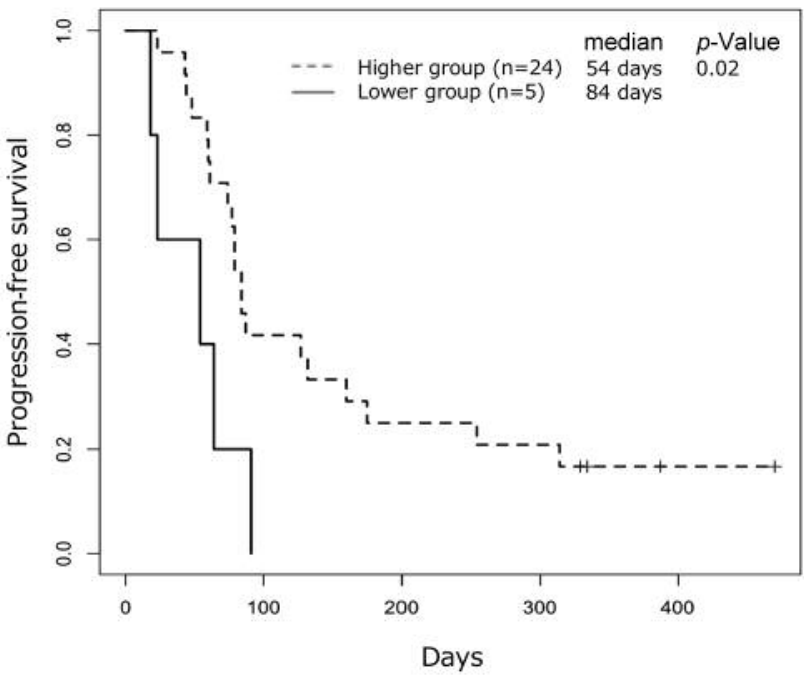

Figure 1. Progression-free survival (PFS). Median PFS time in the Higher group was significantly longer than that in the Lower group. The higher group includes patients with higher pre-treatment IFN- $\gamma$ response to mitogen (7.06 IU/ml or higher). The lower group includes patients with lower pre-treatment IFN- $\gamma$ response to mitogen (under $7.06 \mathrm{IU} / \mathrm{ml}$ ).

Kaplan-Meier method and log-lank test. Categorical variables were compared using the Fisher's exact test. Continuous variables including IFN- $\gamma$ levels were compared using the Wilcoxon rank sum test or Wilcoxon signed-rank test.

\section{Results}

Baseline patient demographics and laboratory data. Table I shows the baseline patient demographics and laboratory data in overall patients $(n=29)$, those $(n=5)$ with $7.06 \mathrm{IU} / \mathrm{ml}$ or less (Lower group), and those $(n=24)$ with more than 7.06 IU/ml (Higher group) in the level of IFN- $\gamma$ of IGRA positive control before ICI treatment. There were no significant differences in patient demographics and laboratory data in both groups except for serum albumin level, which was significantly lower in the Lower group than in the Higher group $(p=0.04)$. On the other hand, neutrophil-lymphocyte ratio and $\mathrm{C}$-reactive protein tended to be higher in the Lower group than in the Higher group. Furthermore, the disease control rate $(0 \%)$ in the Lower group was significantly lower than that $(54.2 \%)$ in the Higher group $(p=0.04)$.

Progression-free survival. As shown in Figure 1, median PFS was 84 days [95\% confidence interval $(\mathrm{Cl})=77-175]$ in the Higher group, which was significantly longer than that in the Lower group with 54 days [95\% Cl-23-not attained (NA)] $(p=0.02)$.

Correlation between response to immune checkpoint inhibitors and interferon-gamma level at pre-treatment or on 
Table II. The levels of IFN- $\gamma$ between PD and non-PD patients and between irAEs group and non-irAEs group.

\begin{tabular}{|c|c|c|c|}
\hline \multirow[t]{2}{*}{ Groups } & \multicolumn{3}{|c|}{ IFN- $\gamma(\mathrm{IU} / \mathrm{ml})$ level (median, range) } \\
\hline & $\mathrm{T} 1$ & $\mathrm{~T} 3$ & $\mathrm{~T} 4$ \\
\hline All patients $(n=29)$ & $28.74(1.43-276.36)$ & $8.59(0.68-185.26)$ & $11.9(0.59-291.12)$ \\
\hline \multicolumn{4}{|l|}{ Response } \\
\hline $\mathrm{PD}(\mathrm{n}=15)$ & $12.98(1.43-273.51)^{\dagger}$ & $3.74(0.68-77.55)^{\dagger}$ & $5.27(0.59-57.09)^{\ddagger}$ \\
\hline Non-PD $(n=13)$ & $82.16(19.55-276.36)$ & $26.5(1.4-185.26)$ & $38.52(1.05-291.12)$ \\
\hline \multicolumn{4}{|c|}{ Immune-related adverse events (irAEs) } \\
\hline $\operatorname{irAE}(+)(n=16)$ & $26.46(3.93-276.36)$ & $8.42(1.29-185.26)^{*}$ & $21.96(0.59-291.12)$ \\
\hline $\operatorname{irAE}(-)(n=13)$ & $34.33(1.43-273.51)$ & $8.59(0.68-114.77)$ & $9.86(0.61-96.17)$ \\
\hline Interstitial pneumonia $+(n=5)$ & $26.36(6.94-166.88)$ & $6.28(1.65-24.95)$ & $3.79(0.59-21.14)$ \\
\hline Interstitial pneumonia $-(n=24)$ & $32.82(1.43-276.36)$ & $15.41(0.68-185.26)$ & $24.37(0.61-291.12)$ \\
\hline
\end{tabular}

Non-PD group: Patients with partial response or stable disease according to RECIST version 1.1. irAEs group: Patients with interstitial pneumonia, fever, eruption, colitis, diabetes mellitus, myositis, or thyroid disorder. ${ }^{\dagger}$ Statistically significant difference with $p$-Value $\leq 0.05$ between PD group and non-PD group. ${ }^{\ddagger}$ Statistically significant difference with $p$-Value $\leq 0.01$ between PD group and non-PD group. *T1 vs. T2 $p=0.0013$.

treatment. As shown in Table II, the median levels of IFN- $\gamma$ in all patients were $28.74 \mathrm{IU} / \mathrm{ml}(\mathrm{T} 1), 8.59 \mathrm{IU} / \mathrm{ml}$ (T3), and $11.90 \mathrm{IU} / \mathrm{ml}$ (T4), respectively. The levels of IFN- $\gamma$ before ICIs in the non-progression disease (non-PD) group, including partial response and stable disease were statistically higher than the progression disease (PD) group at $\mathrm{T} 1$ (82.16 vs. $12.98 \mathrm{IU} / \mathrm{ml}, p=0.015)$ (Figure 2).

Correlation between immune-related adverse events and interferon-gamma levels at pre-treatment or on treatment. As shown in Table II, there was no significant difference in the median level of IFN- $\gamma: 26.46 \mathrm{IU} / \mathrm{ml}$ in patients with irAEs and $34.33 \mathrm{IU} / \mathrm{ml}$ in those without. The median level of IFN- $\gamma$ at T1 in patients with irAEs was significantly decreased in comparison to that at T3 $(26.46 \mathrm{IU} / \mathrm{ml}$ vs. $8.42 \mathrm{IU} / \mathrm{ml}$, $p=0.003)$. On the other hand, there was no statically significant difference in IFN- $\gamma$ levels at T3 between patients with irAEs and those without $(34.33 \mathrm{IU} / \mathrm{ml}$ at T1 vs. $8.59 \mathrm{IU} / \mathrm{ml}$ at T3, $p=0.12$ ). Regarding ICI-induced interstitial pneumonia (ICIIP), the levels of IFN- $\gamma$ were decreased at T1 to T3 in both patient groups with and without ICI-IP. However, low levels of IFN- $\gamma$ in patients with ICI-IP were observed for an extended period of time in comparison to those without (Figure 3 ).

Correlation between tumor proportion score and interferongamma level at pre-treatment. As shown in Figure 4, there was no correlation between IFN- $\gamma$ and PD-L1 TPS (estimated $\mathrm{r}=0.074,95 \% \mathrm{CI}=-0.31-0.44, p=0.71$ ).

\section{Discussion}

In this study, we investigated the association between quantitative IFN- $\gamma$ levels and clinical outcomes in NSCLC patients who received ICIs. In our previous study (10), we
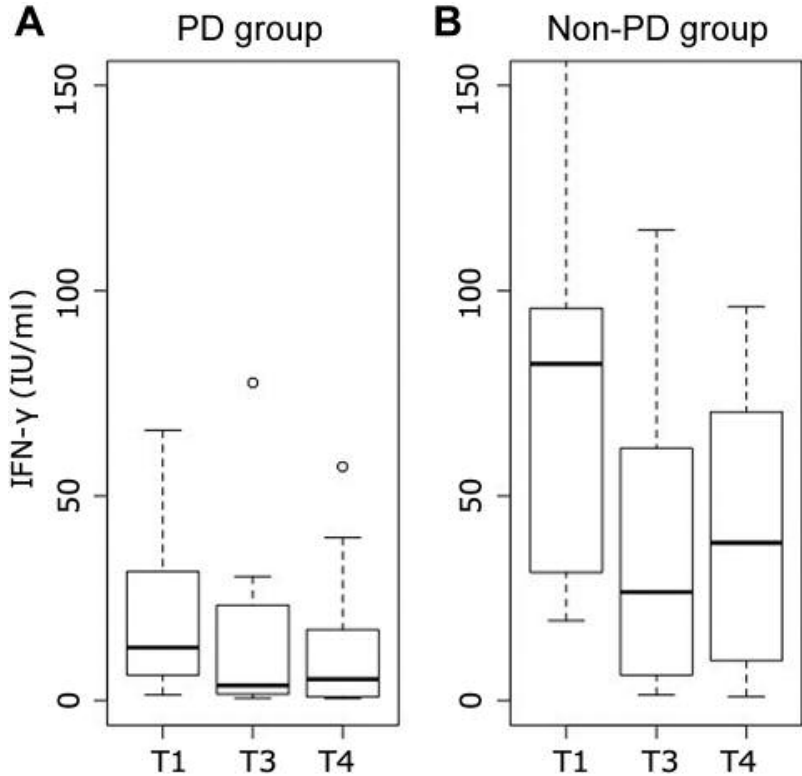

Figure 2. IFN- $\gamma$ levels before ICIs in the non-progression disease (non$P D)$ group were statistically higher than those in the progression disease group at pre-treatment. The non-PD group included stable disease and partial response. There were two patients in the PD group and one in the non-PD group who had IFN- $\gamma$ levels over $150 \mathrm{IU} / \mathrm{ml}$ at T1.

reported that evaluating IFN- $\gamma$ levels in response to mitogen (phytohaemagglutinin), which stimulated $\mathrm{T}$ cell lymphocytes (T-Cell) non-specifically and induced IFN- $\gamma$ release, may be a biomarker for the efficacy of ICIs. However, we had no quantitative data on IFN- $\gamma$ levels over $10 \mathrm{IU} / \mathrm{ml}$ as the upper limit of QFT-Plus. In the present report, we quantitatively showed the detailed change in IFN- $\gamma$ levels over $10 \mathrm{IU} / \mathrm{ml}$. We further demonstrated the correlation between the levels of IFN- 


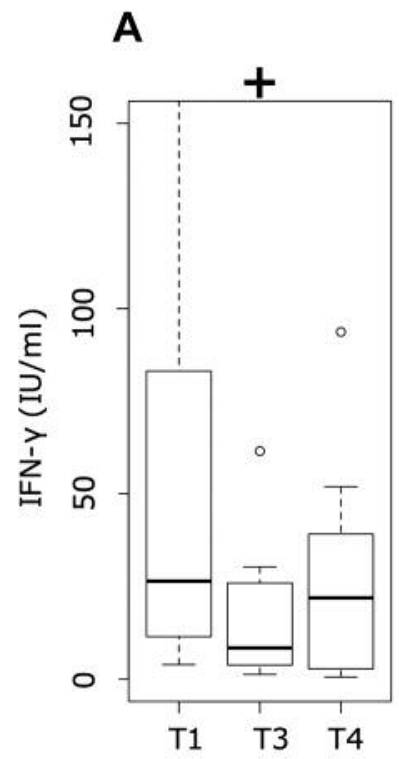

irAEs

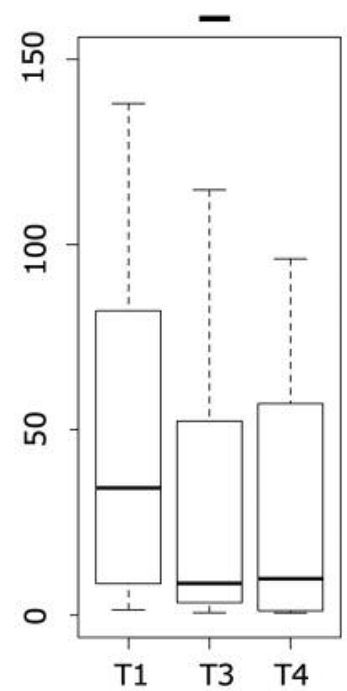

B Interstitial pneumonia

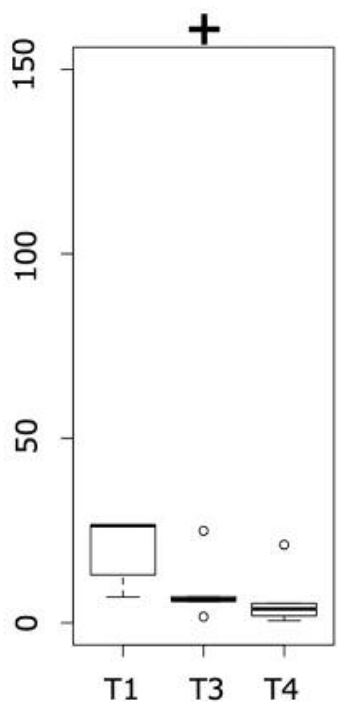

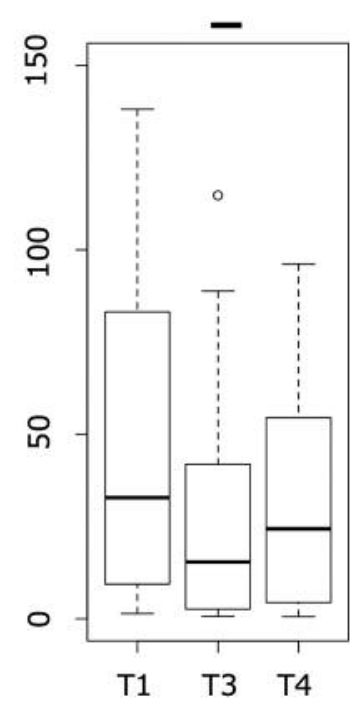

Figure 3. Correlation between immune-related adverse events and interferon-gamma levels at pre-treatment or on treatment. The median IFN- $\gamma$ levels at pre-treatment in patients with irAEs were significantly decreased in comparison to that at T3. On the other hand, there was no statically significant difference in IFN- $\gamma$ levels at T3 between patients with irAEs and those without. There were two patients in the irAE $(+)$ group and one

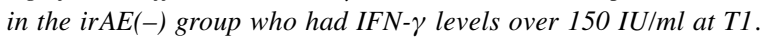

$\gamma$ and clinical outcomes in NSCLC patients who received ICIs. As a result, the patients with IFN- $\gamma$ level of $7.06 \mathrm{IU} / \mathrm{ml}$ or higher at $\mathrm{T} 1$ had significantly longer PFS than those without. On the other hand, at T1, the level of IFN- $\gamma$ in the non-PD group was significantly higher than that in the PD group. To our knowledge, there are no reports that quantitatively examine levels of IFN- $\gamma$ over $10 \mathrm{IU} / \mathrm{ml}$ by the IGRA approach.

In a previous study (11), Huang $\mathrm{HC}$ et al. reported that a higher pre-treatment IFN- $\gamma$ response to PHA $(7.06 \mathrm{IU} / \mathrm{ml}$ or higher), obtained using the IGRA, was associated with better disease control rate and survival among patients with advanced NSCLC treated with chemotherapy. Their results suggested that immunological status in NSCLC patients at pre-treatment would influence response in cytotoxic chemotherapy, too. To test this finding, we re-analysed our data with regards to the new cut-off levels and absolute values of IFN- $\gamma$. The cut-off levels of IFN- $\gamma$ were $10 \mathrm{IU} / \mathrm{ml}$ in our previous report. In that report, the group with IFN- $\gamma$ under 10 $\mathrm{IU} / \mathrm{ml}$ at pre-treatment had higher C-reactive protein (CRP) and lower serum albumin levels. This tendency was preserved as well if the cut-off levels were $7.06 \mathrm{IU} / \mathrm{ml}$.

Niki K et al. showed that IFN- $\gamma$ expression in tumour tissues was associated with response to treatment (13). Westall et al. revealed that IFN- $\gamma$ levels in response to mitogen measured with the QuantiFERON ${ }^{\circledR}$-CMV assay (Cellestis Ltd., Melbourne, Australia) were often negative after early lung transplant, because of immune suppression (14). Changes in

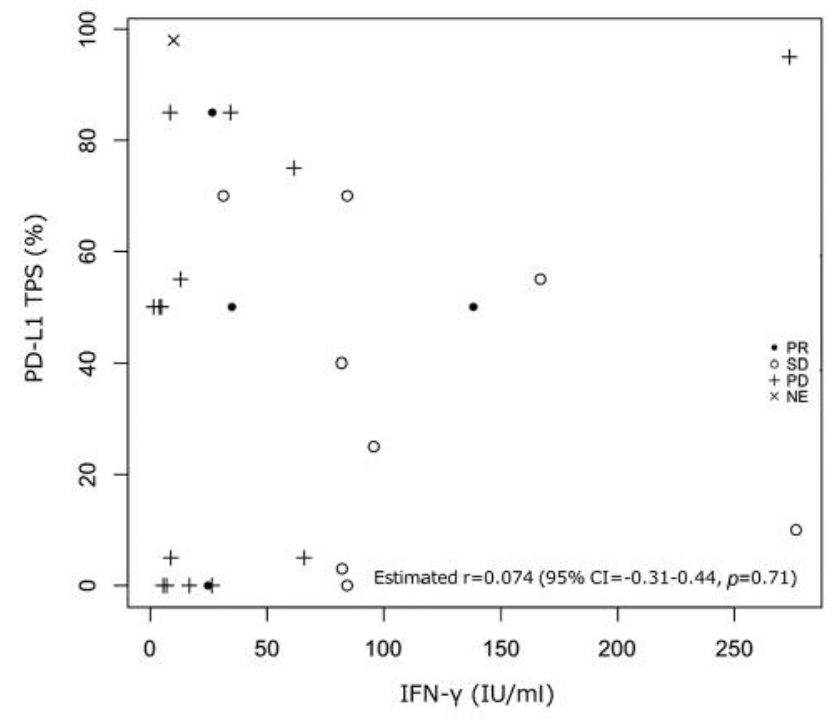

Figure 4. Correlation between programmed cell death-ligand 1 tumour proportion score and interferon-gamma levels at pre-treatment. There was no correlation between IFN- $\gamma$ levels and PD-L1 tumour proportion score.

IFN- $\gamma$ levels in response to mitogen may depend on the immune system condition of the individual patient (15). In our study, low IFN- $\gamma$ levels in response to mitogen before ICIs may also indicate the suppressed immune system state, which could 
be caused by a number of patient conditions, such as age, cancer type, nutrition, inflammation, and performance status. Moreover, Yong et al. recently reported that reduction in T-cell response to mitogen stimulation predicted poor survival in recipients of allogeneic hematopoietic stem cell transplantation (16). Patient's immune system condition is a very important factor for the success of ICI treatment; therefore, the levels of IFN- $\gamma$, especially before treatment, may serve as one of the predictive biomarkers for the response to ICIs.

Furthermore, in this study, the patients who developed irAEs showed significant decrease of IFN- $\gamma$ levels from T1 to day $22 \pm 7$ after ICI treatment. In particular, in patients who developed ICI-IP, decrease in IFN- $\gamma$ levels were observed for an extended period of time, until day $43 \pm 7$. Previous reports suggested that on one hand, early irAEs may predict a good response to ICIs, while on the other hand, severe interstitial pneumonia as an irAE, may result in a poor outcome $(17,18)$. As there seemed to be some patterns of correlation between different types of irAEs and clinical outcomes, there may also be patterns of changes in IFN- $\gamma$ levels in response to each of the irAEs. In recipients of allogeneic hematopoietic stem cell transplantation, Yong et al. (16) reported that patients with low levels of IFN- $\gamma$ in response to mitogen had severe acute graft versus host disease (GVHD), which suggested that this relationship may reflect the immunosuppressive effects of GVHD. Based on their study (16), we also presumed a possibility for the following scenarios: 1) T-Cell in GVHD would recognize a specific antigen in recipients and become cytotoxic $\mathrm{T}$ cell (CTL) responding to that specific antigen, which would cause a loss of response to the non-specific stimulation by mitogen; 2) ICIs would stimulate anti-cancer immune system responses, which would promote T-Cell differentiation into CTL that respond to specific antigen and, subsequently, may remove non-specific response for mitogen. Therefore, we speculated that decrease in the IFN- $\gamma$ levels in patients with irAEs may resemble loss of response for mitogen in severe GVHD. Some studies found a clonal overlap in TCells among blood, tumour, and organs with irAEs $(19,20)$. That indicated that T-Cells overflow from the tumour microenvironment. Thus, we hypothesized that reduction of IFN- $\gamma$ levels in response to mitogen treatment may indicate the presence of overstimulated T-Cells by ICIs in peripheral blood stream, which may induce irAEs.

Teng et al. classified types of tumour microenvironment into four groups based on PD-L1 and IFN- $\gamma$ (21). According to their report, patients with high levels of PD-L1 and IFN$\gamma$ showed good response to ICIs. In the future, if the levels of IFN- $\gamma$ in tumour microenvironment could be easily examined, the prediction of responses to ICI would become more accurate. Limitations of this study include its small sample size and heterogeneity of treatment lines. In addition, we did not have data on IFN- $\gamma$ changes in patients who had no cancer or those who received other anti-cancer agents.
There are no definite data about differences in IFN- $\gamma$ levels based on the types and severity of irAEs. In addition, it is needed to investigate the appropriate time frame for blood examination regarding evaluation of irAEs expression. To overcome these limitations, we intend to perform a prospective study with more patients in the future.

\section{Conclusion}

In this analysis, low levels of IFN- $\gamma$ before treatment were associated with a weak response to ICIs. In addition, the changes in IFN- $\gamma$ levels during ICI treatment may be associated with irAEs. Because of the small sample size, more samples are needed to analyse the correlation between IFN- $\gamma$ levels in response to ICIs and the irAEs.

\section{Conflicts of Interest}

T.H. received honoraria and research funding from Ono Pharmaceutical Co. Ltd. (Osaka, Japan), Lilly Japan Co. Ltd. (Hyogo, Japan), AstraZeneca Co. Ltd. (Osaka, Japan), Taiho Pharmaceutical Co. Ltd. (Tokyo, Japan), Chugai Pharmaceutical Co. Ltd. (Tokyo, Japan), Merck Serono Co. Ltd. (Tokyo, Japan), MSD Oncology Co. Ltd. (Tokyo, Japan), Kyowa-Hakko Kirin, and Boehringer Ingelheim. The other Authors have no conflicts of interest to declare.

\section{Authors' Contributions}

All Authors were involved in the conception and design of the study, or acquisition of data, or analysis and interpretation of data; drafting the article or revising it critically for important intellectual content; and final approval of the version to be submitted. T.K, H.S., Y.S., Y.N., S.N., A.T, N.M., S.H., N.O. and T.H. collected clinical data. H.Y., A.M. and Y.T. performed measurement of QuantiFERON®-TB Gold Plus. H.K. performed blood examination. K.K made a pathological diagnosis. T.K., H.S., T.T., and T.H. performed the statistical analyses.

\section{Acknowledgements}

The Authors would like to appreciate patients and their families. In addition, the Authors also appreciate Mrs. Tani who is our secretary and summarized our data. In addition, the Authors thank Editage (www.editage.jp) for English language editing.

\section{References}

1 Pardoll DM: The blockade of immune checkpoints in cancer immunotherapy. Nat Rev Cancer 12(4): 252-264, 2012. PMID: 22437870. DOI: $10.1038 / \mathrm{nrc} 3239$

2 Ishida Y, Agata Y, Shibahara K and Honjo T: Induced expression of pd-1, a novel member of the immunoglobulin gene superfamily, upon programmed cell death. EMBO J 11(11): 3887-3895, 1992. PMID: 1396582. DOI: 10.1002/j.1460-2075.1992.tb05481.x

3 Brahmer JR, Drake CG, Wollner I, Powderly JD, Picus J, Sharfman WH, Stankevich E, Pons A, Salay TM, McMiller TL, 
Gilson MM, Wang C, Selby M, Taube JM, Anders R, Chen L, Korman AJ, Pardoll DM, Lowy I and Topalian SL: Phase I study of single-agent anti-programmed death-1 (mdx-1106) in refractory solid tumors: Safety, clinical activity, pharmacodynamics, and immunologic correlates. J Clin Oncol 28(19): 3167-3175, 2010. PMID: 20516446. DOI: 10.1200/JCO.2009.26.7609

4 Younes A, Santoro A, Shipp M, Zinzani PL, Timmerman JM, Ansell S, Armand P, Fanale M, Ratanatharathorn V, Kuruvilla J, Cohen JB, Collins G, Savage KJ, Trneny M, Kato K, Farsaci B, Parker SM, Rodig S, Roemer MG, Ligon AH and Engert A: Nivolumab for classical hodgkin's lymphoma after failure of both autologous stem-cell transplantation and brentuximab vedotin: A multicentre, multicohort, single-arm phase 2 trial. Lancet Oncol 17(9): 1283-1294, 2016. PMID: 27451390. DOI: 10.1016/S1470-2045(16)30167-X

5 Kang YK, Boku N, Satoh T, Ryu MH, Chao Y, Kato K, Chung HC, Chen JS, Muro K, Kang WK, Yeh KH, Yoshikawa T, Oh SC, Bai LY, Tamura T, Lee KW, Hamamoto Y, Kim JG, Chin K, Oh DY, Minashi K, Cho JY, Tsuda M and Chen LT: Nivolumab in patients with advanced gastric or gastro-oesophageal junction cancer refractory to, or intolerant of, at least two previous chemotherapy regimens (ono-4538-12, attraction-2): A randomised, double-blind, placebo-controlled, phase 3 trial. Lancet 390(10111): 2461-2471, 2017. PMID: 28993052. DOI: 10.1016/S0140-6736(17)31827-5

6 Brahmer J, Reckamp KL, Baas P, Crino L, Eberhardt WE, Poddubskaya E, Antonia S, Pluzanski A, Vokes EE, Holgado E, Waterhouse D, Ready N, Gainor J, Aren Frontera O, Havel L, Steins M, Garassino MC, Aerts JG, Domine M, Paz-Ares L, Reck M, Baudelet C, Harbison CT, Lestini B and Spigel DR: Nivolumab versus docetaxel in advanced squamous-cell nonsmall-cell lung cancer. N Engl J Med 373(2): 123-135, 2015. PMID: 26028407. DOI: 10.1056/NEJMoa1504627

7 Borghaei H, Paz-Ares L, Horn L, Spigel DR, Steins M, Ready NE, Chow LQ, Vokes EE, Felip E, Holgado E, Barlesi F, Kohlhaufl M, Arrieta O, Burgio MA, Fayette J, Lena H, Poddubskaya E, Gerber DE, Gettinger SN, Rudin CM, Rizvi N, Crino L, Blumenschein GR Jr., Antonia SJ, Dorange C, Harbison $\mathrm{CT}$, Graf Finckenstein $\mathrm{F}$ and Brahmer JR: Nivolumab versus docetaxel in advanced nonsquamous non-small-cell lung cancer. N Engl J Med 373(17): 1627-1639, 2015. PMID: 26412456. DOI: 10.1056/NEJMoa1507643

8 Darvin P, Toor SM, Sasidharan Nair V and Elkord E: Immune checkpoint inhibitors: Recent progress and potential biomarkers. Exp Mol Med 50(12): 165, 2018. PMID: 30546008. DOI: 10.1038/s12276-018-0191-1

9 Nakamura Y: Biomarkers for immune checkpoint inhibitormediated tumor response and adverse events. Front Med (Lausanne) 29(6): 119, 2019. PMID: 31192215. DOI: 10.3389/ fmed.2019.00119

10 Hirashima T, Kanai T, Suzuki H, Yoshida H, Matsushita A, Kawasumi H, Samejima Y, Noda Y, Nasu S, Tanaka A, Morishita $\mathrm{N}$, Hashimoto S, Kawahara K, Tamura Y, Okamoto N and Tanaka T: The levels of interferon-gamma release as a biomarker for non-small-cell lung cancer patients receiving immune checkpoint inhibitors. Anticancer Res 39(11): 6231-6240, 2019. PMID: 31704852. DOI: 10.21873/anticanres.13832

11 Huang HC, Su WJ, Chiang CL, Feng JY, Huang HY, Lin CH, Lin $\mathrm{SH}$, Cheng $\mathrm{CY}$ and Chiu $\mathrm{CH}$ : The predictive value of the interferongamma release assay for chemotherapy responses in patients with advanced non-small-cell lung cancer. Lung Cancer 115: 64-70, 2018. PMID: 29290264. DOI: 10.1016/j.lungcan.2017.11.016

12 R.C. Team, The R Profect for Statistical Computing Available at: https://www.r-project.org [Last accessed on March 20, 2020]

13 Karachaliou N, Gonzalez-Cao M, Crespo G, Drozdowskyj A, Aldeguer E, Gimenez-Capitan A, Teixido C, Molina-Vila MA, Viteri S, De Los Llanos Gil M, Algarra SM, Perez-Ruiz E, Marquez-Rodas I, Rodriguez-Abreu D, Blanco R, Puertolas T, Royo MA and Rosell R: Interferon gamma, an important marker of response to immune checkpoint blockade in non-small cell lung cancer and melanoma patients. Ther Adv Med Oncol 10: 1758834017749748, 2018. PMID: 29383037. DOI: 10.1177/ 1758834017749748

14 Westall GP, Mifsud NA and Kotsimbos T: Linking $\mathrm{cmv}$ serostatus to episodes of $\mathrm{cmv}$ reactivation following lung transplantation by measuring cmv-specific cd8+t-cell immunity. Am J Transplant 8(8): 1749-1754, 2008. PMID: 18557732. DOI: 10.1111/j.1600-6143.2008.02294.x

15 Belliere $\mathrm{J}$ and Blancher A: Quantiferon test interpretation in patients receiving immunosuppressive agents: An alert. Eur Respir J 49(4): 1602102, 2017. PMID: 28381433. DOI: 10.1183/13993003.02102-2016

16 Yong MK, Cameron PU, Slavin MA, Cheng AC, Morrissey CO, Bergin K, Spencer A, Ritchie D and Lewin SR: Low t-cell responses to mitogen stimulation predicts poor survival in recipients of allogeneic hematopoietic stem cell transplantation. Front Immunol 8: 1506, 2017. PMID: 29170666. DOI: 10.3389/fimmu.2017.01506

17 Teraoka S, Fujimoto D, Morimoto T, Kawachi H, Ito M, Sato Y, Nagata K, Nakagawa A, Otsuka K, Uehara K, Imai Y, Ishida K, Fukuoka J and Tomii K: Early immune-related adverse events and association with outcome in advanced non-small cell lung cancer patients treated with nivolumab: A prospective cohort study. J Thorac Oncol 12(12): 1798-1805, 2017. PMID: 28939128. DOI: $10.1016 /$ j.jtho.2017.08.022

18 Tone M, Izumo T, Awano N, Kuse N, Inomata M, Jo T, Yoshimura $\mathrm{H}$, Minami J, Takada K, Miyamoto S and Kunitoh H: High mortality and poor treatment efficacy of immune checkpoint inhibitors in patients with severe grade checkpoint inhibitor pneumonitis in nonsmall cell lung cancer. Thorac Cancer 10(10): 2006-2012, 2019. PMID: 31482678. DOI: 10.1111/1759-7714.13187

19 Gros A, Parkhurst MR, Tran E, Pasetto A, Robbins PF, Ilyas S, Prickett TD, Gartner JJ, Crystal JS, Roberts IM, TrebskaMcGowan K, Wunderlich JR, Yang JC and Rosenberg SA: Prospective identification of neoantigen-specific lymphocytes in the peripheral blood of melanoma patients. Nat Med 22(4): 433438, 2016. PMID: 26901407. DOI: 10.1038/nm.4051

20 Laubli H, Koelzer VH, Matter MS, Herzig P, Dolder Schlienger B, Wiese MN, Lardinois D, Mertz KD and Zippelius A: The t cell repertoire in tumors overlaps with pulmonary inflammatory lesions in patients treated with checkpoint inhibitors. Oncoimmunology 7(2): e1386362, 2018. PMID: 29308309. DOI: $10.1080 / 2162402 X .2017 .1386362$

21 Teng MW, Ngiow SF, Ribas A and Smyth MJ: Classifying cancers based on t-cell infiltration and pd-11. Cancer Res 75(11): 2139-2145, 2015. PMID: 25977340. DOI: 10.1158/0008-5472.CAN-15-0255

Received March 12, 2020

Revised March 23, 2020

Accepted March 26, 2020 